\title{
Alternative hydraulic binder development based on brick fines: influence of particle size and substitution rate
}

Adèle Grellier ${ }^{\mathrm{a}, \mathrm{b}}$, David Bulteel ${ }^{\mathrm{a}}$, Mohamed El Karim Bouarroudj ${ }^{\mathrm{a}, \mathrm{b}}$, Sébastien Rémond ${ }^{\mathrm{a}, \mathrm{c}}$, Zengfeng Zhao ${ }^{\mathrm{b}}$, Luc Courard ${ }^{\mathrm{b}}$

a Univ. Lille, IMT Lille Douai, ULR 4515 - LGCgE, Laboratoire de Génie Civil et GéoEnvironnement, F-59000 Lille, France

b University of Liège, Urban and Environnemental Engineering, GeMMe Building materials, Liège, Belgium

c Univ Orléans, Univ Tours, INSA CVL, LaMé, EA 7494, France

Abstract: Brick waste is produced in large quantities by the civil engineering sector without any real valorization. One way of valorizing this material consists in incorporating brick fines in cement. The substitution of clinker with this material produces an alternative hydraulic binder. In addition to the reduction in cost and energy saving, blended cement based on brick fines would present the advantage to improve the environmental impact of cement production by reducing its $\mathrm{CO}_{2}$ emission. Therefore, the aim of this paper is to study the use of bricks fines in cement, focusing more specifically on the impact of the size of their particles on fresh and hardened cement paste properties. Potential pozzolanic activity of the three brick fines was investigated as well as its influence on the microstructure and strength of cement paste samples. The results showed that it was possible to produce blended cement based on brick fines. Substitution rates up to $20 \%$ with brick fines whose dimensions are close to those of clinker gave good performances compared to the reference cement. The brick fines clearly impact the hydration process through nucleation action and pozzolanic activity.

Keywords: brick fines, cement, hydraulic binders, pozzolanicity, microstructure

*Corresponding author: Grellier, Adèle

GeMMe Building materials, Urban and Environmental Engineering, University of Liège

Allée de la Découverte, 9 - 4000 LIEGE (Belgium)

Phone : +32.6 .28 .06 .22 .83$

Email : adele.grellier@doct.uliege.be 


\section{Introduction}

The cement industry and construction companies are facing significant economic and environmental challenges. On the one hand, they have to reduce the $\mathrm{CO}_{2}$ emissions associated with the fabrication of cement [1,2]. On the other hand, they need to manage the growing amount of Construction and Demolition Waste (C\&DW). According to a European directive (2008/98/EC), 70\% of this C\&DW must be reused or recycled by 2020 [3].

One of these material flows of C\&DW has been identified as being made of silicate materials: bricks and tiles, which were widely used in the construction of houses at the end of the $19^{\text {th }}$ and the beginning of the $20^{\text {th }}$ centuries, specifically in Belgium and Northern France.

The manufacturing of bricks involves a transformation of clay as a raw material, which is fired at high temperatures. Depending on the quality of the clay as well as the used temperatures, the composition of the resulting brick will change. When clay is heated to temperatures of around $800-900^{\circ} \mathrm{C}$, the crystalline structure of the silicate phase partly transforms into amorphous phase [4]. A widely studied example is that of the transformation of kaolinite into metakaolin, a product used as a pozzolanic addition in concrete [5]. At temperatures above $1000^{\circ} \mathrm{C}$, the partial fusion of oxides leads to the production of a crystalline phase, rich in quartz and aluminosilicates. Remaining amorphous compounds associated with the high levels of silica and aluminate in the bricks make it possible to obtain a material that is highly reactive to the products of cement hydration [6,7], specifically in former products where conditions of firing were not perfect and transformation of oxides was not fully completed [8]. An interesting alternative for supplementary cementitious materials would be to substitute, as it is the case for cement, a part of a material known as fly ash or blast furnace slag with brick fines in order to develop materials with proper physical and mechanical performances [9,11]. Substituting cement by brick fines particles in concrete seems to give very good performances [12]. The addition of silicate materials in the form of brick fines results in a minor loss of strength but would increase durability performances; these results are due to the pozzolanic properties of the brick fines $[6,9,12-17]$. Low substitution rates with different particle sizes are possible; studies are pointing out a specific contribution of these fines in a hydraulic binder [12,18-20]. The objective of this study is to investigate the use of brick fines when ground into three different particle sizes and incorporated in blended cement in order to observe their impact on 
fresh and hardened cement paste properties. The reactivity of brick fines - specifically pozzolanic activity - was investigated in particular.

\section{Materials and methods}

\subsection{Brick fines characterization}

The main material used was a brick type HB780 (high strength block, 288 x 138 x $138 \mathrm{~mm}$ ) recovered from a Belgian brickyard in Ploegsteert and called reference brick. Working with a reference brick makes it possible to overcome defects that could be present within recycled brick polluted by other materials (concrete, plasters, coatings...).

Three reference particle sizes were used to investigate the effect of fineness in mixes: B1 ( $D_{50}$ $3.2 \mu \mathrm{m}), \mathrm{B} 2\left(\mathrm{D}_{50} 20.7 \mu \mathrm{m}\right)$ and B3 ( $\left.\mathrm{D}_{50} 180 \mu \mathrm{m}\right)$. The preparation of the different brick fines consisted in reducing the dimensions with a jaw crusher and a ball mill during 10 min for B3 and $40 \mathrm{~min}$ for B2. In addition, a ring crusher was used for the production of the ultrafine particles B1.

In this study, paste mixes with mass substitution of Portland cement by the three brick fines were studied. The Portland cement used is a EQIOM cement CEM I $52.5 \mathrm{~N}$.

\subsubsection{Mineralogical and chemical analyses}

The mineralogical composition of the brick fines was defined by X-ray diffraction (XRD) with Brucker AXS D2 phaser diffractometer (6-80 angle, $0.2^{\circ}$ pitch and acquisition time $\left.0.5 \mathrm{~s}\right)$. The Rietveld refinement method was applied to quantify the crystalline phases and amorphous phase part [21]. The chemical composition of the brick fines was determined by X-ray fluorescence (XRF).

\subsubsection{Physical analysis}

The particle size distribution of the brick fines was determined by a Beckman Coulter LS I3 320 laser. The three brick fines B1, B2, and B3 were compared to the cement CEM I 52.5 N and the results are presented in Figure 1. As expected from the preparation process, the particle 
size increased between B1 and B3. These three types of fines allow a study on their impact on cement binder's properties.

The specific surface area (BET method) was correlated to the pozzolanic activity of brick fines particles.

Water absorption (WA) was calculated based on previous work [22], via the formulation in equation 1. First of all, the intraganular porosity $\left(\phi_{r}\right)$ of the three brick fines must be calculated based on Bouarroudj's model. This porosity evolves with the particle size distribution and the porosimetry of the monolith brick. With the intragranular porosity, the calculation of the absorption can be carried out based on the absolute density of the brick fines. The absolute density $\left(\rho_{\mathrm{a}}\right)$ was measured with a helium pycnometer, according to NF EN 1097-7 [23] and amounted to $2.86 \mathrm{~g} / \mathrm{cm}^{3}$.

$$
\mathrm{WA}=\frac{\phi_{r}}{\rho_{a} \times\left(1-\phi_{r}\right)}
$$

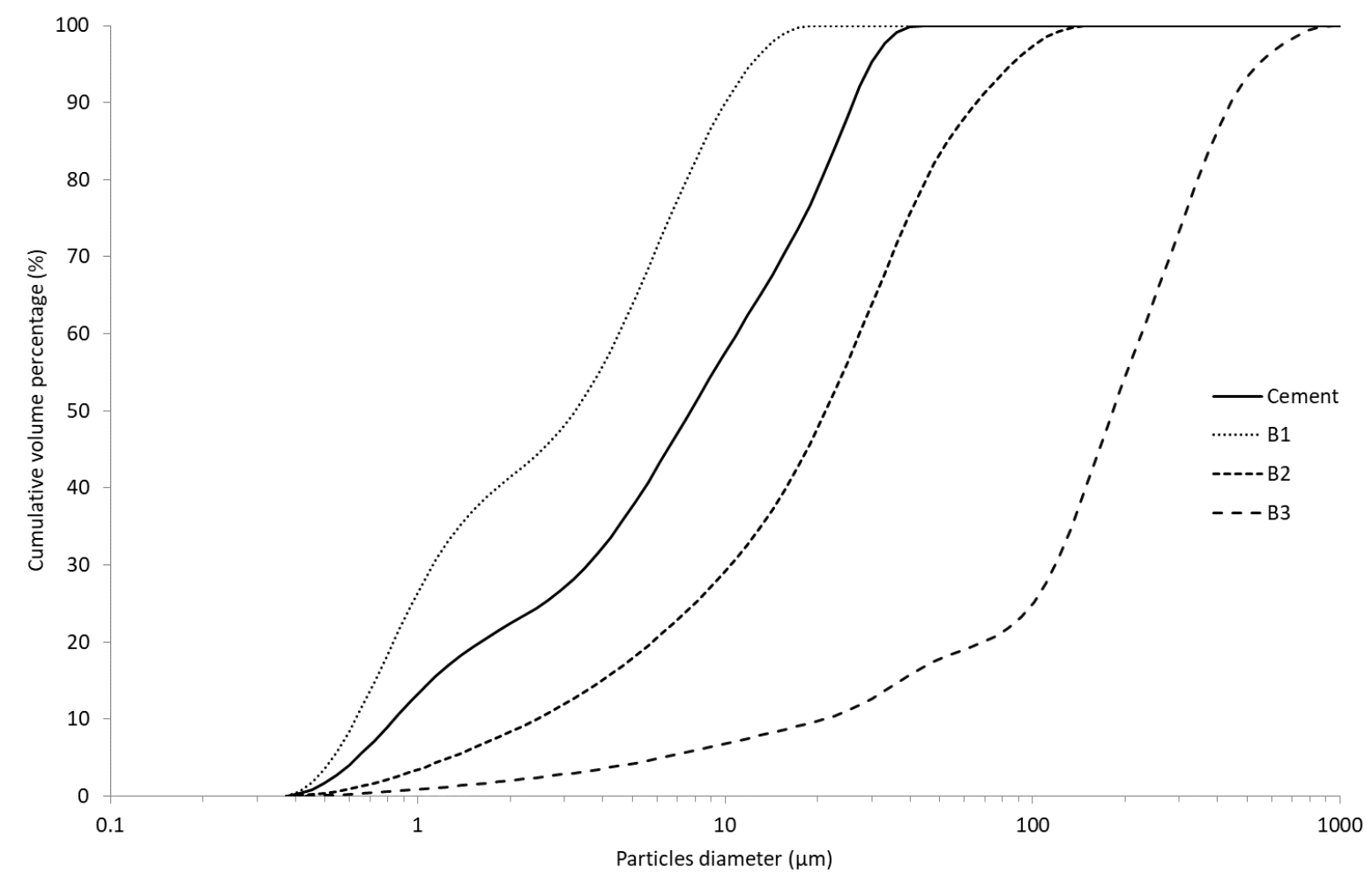

Figure 1 Particle size distribution of brick fines and cement CEM I $52.5 \mathrm{~N}$. 


\subsubsection{Pozzolanic activity}

The evaluation of the pozzolanic activity of the brick fines was carried out with the modified Chapelle test NF EN 196-5 [24]. According to the American standard ASTM C618-05 [25], a natural pozzolan is a siliceous or silico-aluminous material which does not have binding properties itself but which, finely grinded and in the presence of moisture, reacts chemically with calcium hydroxide at room temperature to form compounds having binding properties. The Chapelle test consists in evaluating the quantity of lime fixed by the brick fines. This quantity of fixed lime corresponds to the pozzolanic activation of the brick fines. The bricks could fix between 350 and $400 \mathrm{mg}$ of lime per g of bricks [26].

\subsection{Cement paste preparation}

Cement pastes were designed with the three reference brick fines (B1, B2 and B3) and cement CEM I $52.5 \mathrm{~N}$, the mix proportions are presented in Table 1. The percentage of brick fines in the samples is indicated by the substitution rates in mass \%. Four levels of substitution were studied: $10 \%, 20 \%, 30 \%$, and $80 \%$. This $80 \%$ rate was used to reveal the potential reactivity of the brick fines.

Following the water absorption calculation, the amount of water in the formulations will be fixed to achieve a water/binder ratio=0.45 (W/B, where binder $=$ cement + brick fines $)$. This W/B allows for a good workability of the pastes with the three brick fines and up to $80 \%$ substitution.

The properties of cement pastes with brick fines were studied to understand the impact of the substitution of brick fines in the mix as well as the impact of particle size distribution of brick fines. A precise mixing procedure was followed according to the European standard NF EN 196-1 [27]. The mixing protocol was kept the same for all the studied cement pastes.

Specimens were molded $\left(4 \times 4 \times 16 \mathrm{~cm}^{3}\right.$ mold $)$ and stored in a climatic room at $20 \pm 2{ }^{\circ} \mathrm{C}$ and 50 $\pm 5 \%$ relative humidity; they were demolded after $24 \mathrm{~h}$. 
Table 1-Mix proportions.

\begin{tabular}{cccccc}
\hline Type & Cement & $10 \%$ & $20 \%$ & $30 \%$ & $80 \%$ \\
\hline Cement CEM I 52.5 N (g) & 3000 & 2700 & 2400 & 2100 & 600 \\
Brick fines (B1/B2/B3) (g) & 0 & 300 & 600 & 900 & 2400 \\
Water (g) & 1350 & 1350 & 1350 & 1350 & 1350 \\
W/B & 0.45 & 0.45 & 0.45 & 0.45 & 0.45 \\
with Binder= Cement + Brick fines & & & & & \\
\hline
\end{tabular}

\subsection{Fresh state characterization}

The slump test was performed with an adaptation of the standard method for mortars, NF EN 1015-3 [28] for paste conditions, with a specific dimension cone $(\mathrm{d}=5 \mathrm{~cm}, \mathrm{D}=10 \mathrm{~cm}, \mathrm{H}=5 \mathrm{~cm})$. The slump flow result was obtained by average value measured on two perpendicular diameters. The setting time was measured with an automatic Vicat apparatus according to the European standard NF EN 196-3 [29].

\subsection{Characterization of hardened cement pastes}

\subsubsection{Porosimetry analysis}

A Mercury Intrusion Porosimeter (MIP) was used to study the total porosity and the pore size distribution of the cement pastes. A Micrometritics autopore IV with a mercury pressure ranging between 0 and $200 \mathrm{MPa}$ was used. Hydration was stopped in an acetone bath for 1 week and then dried at $40^{\circ} \mathrm{C}$ for each sample after 1, 7, 28 and 90 days.

\subsubsection{Thermogravimetric analysis}

A thermogravimetric analysis (TGA) was performed using a simultaneous TG-DTA model NETZSCH STA $449 \mathrm{~F} 3$ Jupiter. The selected heating ramp was $10^{\circ} \mathrm{C} / \mathrm{min}$ up to $1000{ }^{\circ} \mathrm{C}$. The percentage of portlandite and carbonates formed in the mixtures was calculated using the derivative of the TGA curve versus temperature. 


\subsubsection{Compressive strength}

The compressive strength tests were carried out on $4 \mathrm{~cm}^{3}$ specimens with an Instron $150 \mathrm{kN}$ press NF EN 196-1 [27]. Specimens were taken by cutting from a larger 4x4x16 cm 3 sample.

\subsubsection{Energetic production}

The energy production for material processing as well as the $\mathrm{CO}_{2}$ emission were evaluated using Ecoinvent 3.5 data and calculated according to method CML-IA baseline V3.05 [30,31].

\section{Results and discussion}

\subsection{Brick fines characterization}

\subsubsection{Mineralogical and chemical analyses}

The composition in oxide elements is presented in Table 2. The major elements were $\mathrm{SiO}_{2}$, $\mathrm{Fe}_{2} \mathrm{O}_{3}$ and $\mathrm{Al}_{2} \mathrm{O}_{3}$. Mineralogical results, presented in Figure 2, show a majority of quartz, which is the main siliceous phase. A presence of iron oxide (hematite), potassium and sodium feldspars (intermediate microcline, albite) as well as an amorphous phase $16 \%$, quantified with the Reitveld method was also noted [32]. This brick fines composition corresponds to that of classical bricks. This amorphous phase could produce a pozzolanic reaction, and thus contribute to an improvement of the hydration process when the cement will be substituted by the brick fines $[33,34,14]$. 
Table 2-Chemical composition of brick fines.

\begin{tabular}{cc}
\hline Elements (\% oxides) & Brick fines \\
\hline $\mathrm{Na}_{2} \mathrm{O}$ & 0.6 \\
$\mathrm{MgO}$ & 2.2 \\
$\mathrm{Al}_{2} \mathrm{O}_{3}$ & 10.4 \\
$\mathrm{SiO}_{2}$ & 62.8 \\
$\mathrm{SO}_{3}$ & 0.6 \\
$\mathrm{~K}_{2} \mathrm{O}$ & 2.1 \\
$\mathrm{CaO}$ & 1.7 \\
$\mathrm{TiO}_{2}$ & 2.4 \\
$\mathrm{~V}_{2} \mathrm{O}_{5}$ & 0.1 \\
$\mathrm{MnO}$ & 0.2 \\
$\mathrm{Fe}_{2} \mathrm{O}_{3}$ & 16.3 \\
$\mathrm{BaO}$ & 0.2 \\
$\mathrm{Total}$ & 99.6 \\
\hline
\end{tabular}

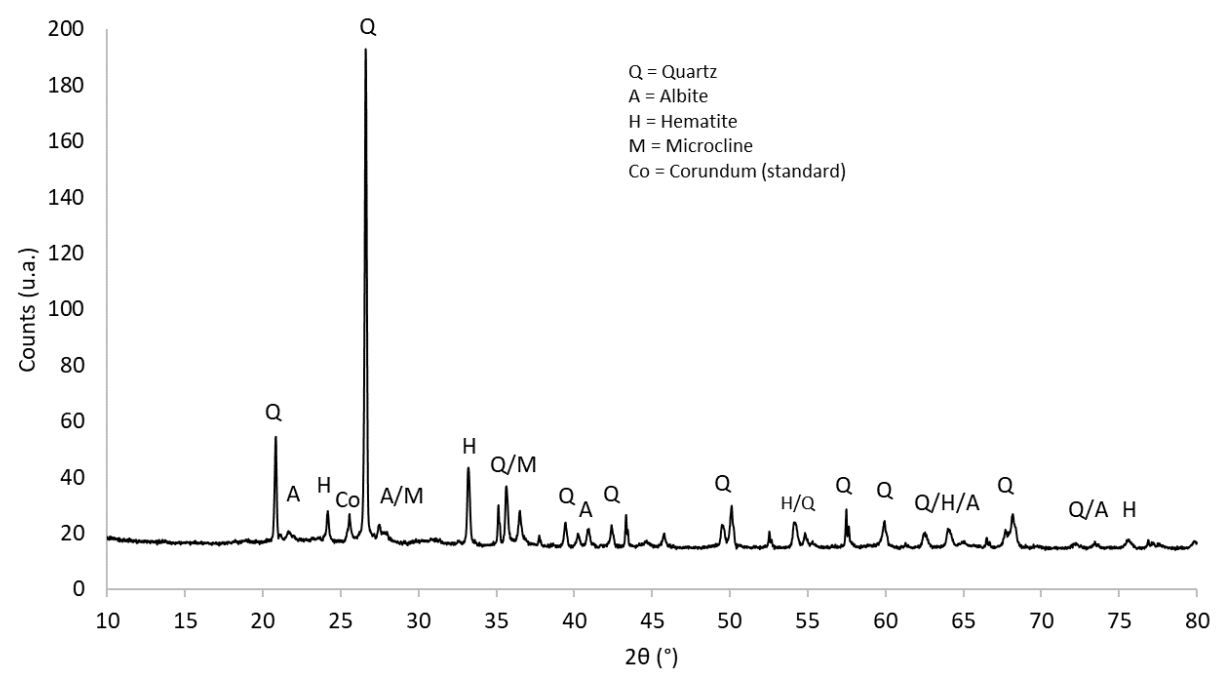

Figure 2 XRD pattern of brick fines. 


\subsubsection{Physical properties of binder materials}

The particle sizes of the different materials are shown in Table 3, as well as the specific surface area and pozzolanic activity. The particle size of cement was between that of B1 and B2. The materials were defined according to their $\mathrm{D}_{50}$ values: B1 is the finest, followed by cement, B2 and B3, respectively.

The activating power of brick fines is indicated by their pozzolanic activity. This reaction is correlated to the size of particles and their specific surface area (BET), taking into account that the mineralogical composition was the same for all materials used here. This pozzolanic activity can be compared to other materials used as additions. The pozzolanic activity of brick fines lies between that of blast furnace slag and silica fume [35,36].

The water absorption of B1, B2 and B3 was $0 \%, 1.1 \%$ and $2.2 \%$ respectively, in comparison to the water absorption of brick monolith (11\%): a large part of the porosity has been opened during the grinding and crushing procedure.

Table 3-Characteristics of brick fines.

\begin{tabular}{lcccc}
\hline Type & Cement & B1 & B2 & B3 \\
\hline $\mathrm{D}_{10}(\mu \mathrm{m})$ & 0.86 & 0.65 & 2.42 & 20.7 \\
$\mathrm{D}_{50}(\mu \mathrm{m})$ & 8.1 & 3.2 & 20.7 & 180 \\
$\mathrm{D}_{90}(\mu \mathrm{m})$ & 27.3 & 9.8 & 63.4 & 449 \\
Specific surface & 1470 & 3169 & 868 & 184 \\
area $\left(\mathrm{m}^{2} / \mathrm{kg}\right) \mathrm{BET}$ & & & & \\
Pozzolanic activity & - & 622 & 394 & 294 \\
$\left(\mathrm{Ca}(\mathrm{OH})_{2} \mathrm{mg} / \mathrm{g}\right)$ & & & & \\
Water absorption & & & & \\
$(\%)$ & - & 0 & 1.1 & 2.2 \\
\hline
\end{tabular}




\subsection{Fresh state analysis}

\subsubsection{Slump test}

The slump test was carried out on mixes with the three particle sizes and substitution rates of 10, 20, 30 and $80 \%$ of brick fines; the results are shown in Figure 3. For substitutions with B1 fines, the slump flow decreased with the increasing proportion of brick fines: $148 \mathrm{~mm}$ for $10 \%$ and $100 \mathrm{~mm}$ for $80 \%$. A different behavior was noted for B2 and B3 fines. Slump with these brick fines (B2 and B3 fines) slightly increased with the increasing of substitution rate. For B2 fines, the slump was $155 \mathrm{~mm}$ for $10 \%$ and $187 \mathrm{~mm}$ for $80 \%$. For the B3 fines, the difference was more marked with a slump from $181 \mathrm{~mm}$ at $10 \%$ to $300 \mathrm{~mm}$ at $80 \%$. Comparing with a reference cement paste, the paste produced with 10\% B1 and B2 fines substitution rates showed similar slump value. When the substitution increased, the behavior of the paste differed. For B1 fines, workability decreased with the increasing proportion of brick fines, whereas for B2 and B3 fines, workability increased with an increasing substitution rate. The difference in workability does not seem to be due to water absorption of brick fines. The water absorption of the brick was $11 \%$ when determined on the basis of the IFSTTAR method on particles of 0-30 $\mathrm{mm}$ [37] which corresponds to the porosity of the initial brick. Grinding is largely eliminating porosity and thus water absorption (Table 3). Decreasing workability of the cement paste with B1 fines is probably due to a greater specific surface area and water demand due to higher quantities of fine particles. In contrast, the workability of cement pastes with B2 and B3 particles is increasing with the increase of substitution rate of brick fines, which is probably due to the higher packing density of mix (the larger particle size and the particle size distributions of B2 and B3 can induce a higher packing density), resulting in the decrease of free water needed for flow: this results in the increasing workability of cement pastes with B2 and B3 particles.

Slump variations found in mixtures with higher substitution rates (more than 30\%) of brick fines B2 and B3 could be corrected by reducing the amount of water. In this way, the parameters of porosity and mechanical resistance could also be improved. 


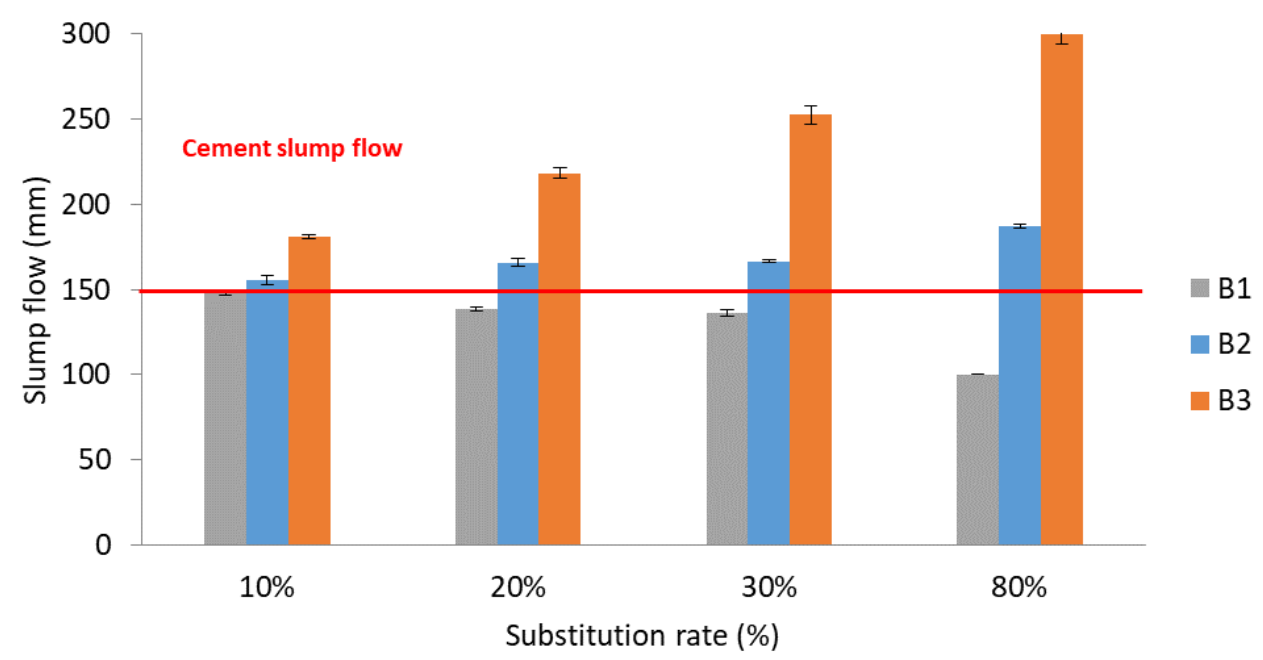

Figure 3 Slump of pastes with brick fines (red line refers to the slump flow of reference cement paste).

\subsubsection{Setting time}

With cement substitued by brick, the setting time changed. Generally with additions of the metakaolin or silica fume type, the setting time is delayed [38]. In this study, for the initial setting time as well as for the final setting time, the increasing proportion of brick fines increased both setting times, seen in Figure 4. However, for low substitution rates (10 and 20\%), the setting times remained close to the control cement. In the case of mixtures with $10 \%$ and $20 \%$ B1 fines, the final setting time was smaller than that of cement and with the other fines. Due to the fineness of the B1 samples, a probable nucleation effect accelerates the setting. With mixtures up to $30 \%$ substitution rates, the setting time of all pastes (B1-30\%, B2-30\% and B3$30 \%$ ) remains close to that of the control paste (no more than 2 hours excess for the initial setting time). The same trend has been observed for the final setting time. 


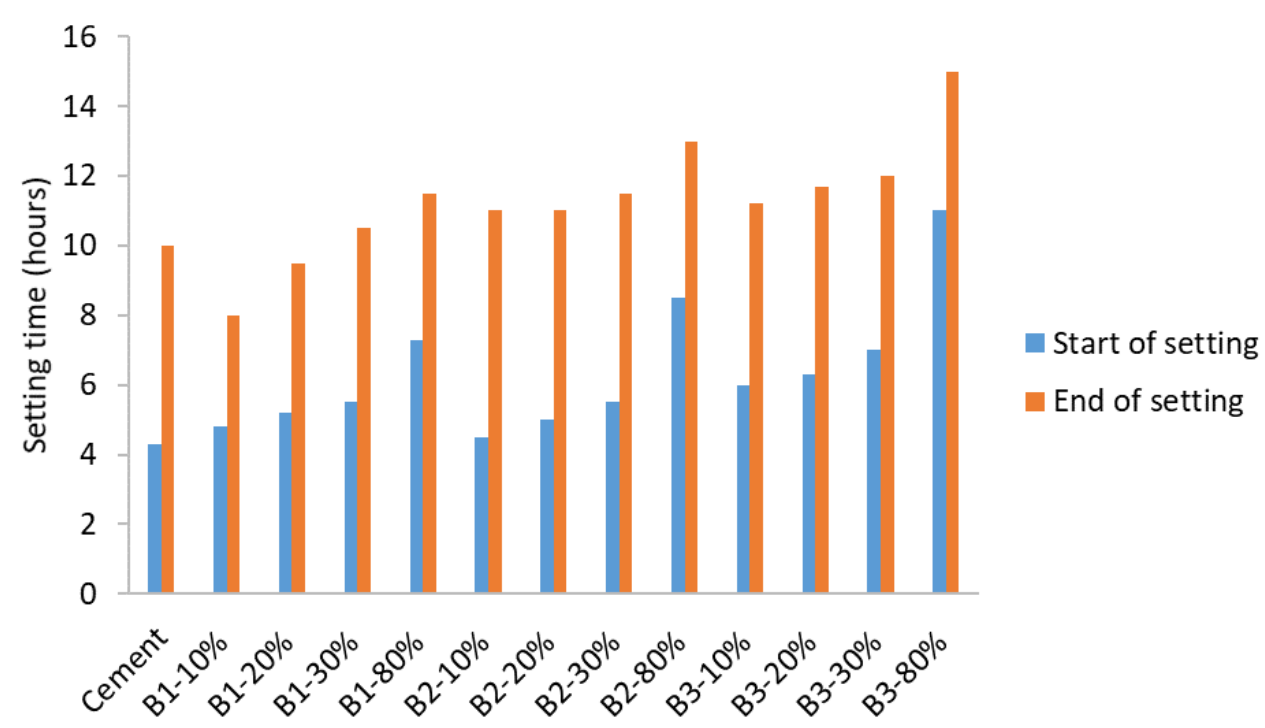

Figure 4-Setting time versus mixes with brick fines.

\subsection{Hardened properties of cement pastes}

\subsubsection{The pozzolanic activity estimated by thermogravimetric analysis}

Thermogravimetric analyses were used to calculate the amount of portlandite based on the amount of cement in each sample in Figure 5. The contents obtained in portlandite were the result of a competition between the hydration reaction of the cement which generated it and the pozzolanic reaction which consumed it.

There was small differences between cement and brick fines as well as between specimens of brick fines. But, the cement was properly hydrated in all samples. At a young age, the quantity of portlandite was close to the one of B2 and B3 samples and it was increased for mixtures with B1 fines compared to the control cement. For the sample with $80 \%$ substitution of fines B1, the behavior at young age but also at 90 days was lower from the other substitutions. The poor workability with the addition of B1 fines would cause these atypical results. The hydration and pozzolanic reactions are not equivalent at the same age for the pastes made with the three types of brick fines. For the paste made with B1 fines at 1 day, the amount of Portlandite in the mixtures is equivalent or even slightly higher than in the reference paste, except for mixture B1-80\%. It means that the mixtures with B1 fines could accelerate the hydration reaction 
process through a greater nucleation effect (due to their fineness) than for pastes with the B2 and $\mathrm{B} 3$ fines.

At 28 days, the amount of Portlandite in the mixtures with 10 and $20 \%$ of fines, respectively, was lower than in the reference paste, which was due to the initiation of the consumption of Portlandite by pozzolanic reaction.

For the pastes produced with B2 and B3 fines, the pozzolanic reaction effects are only clearly visible for a higher substitution rate $(80 \%)$ at 90 days.

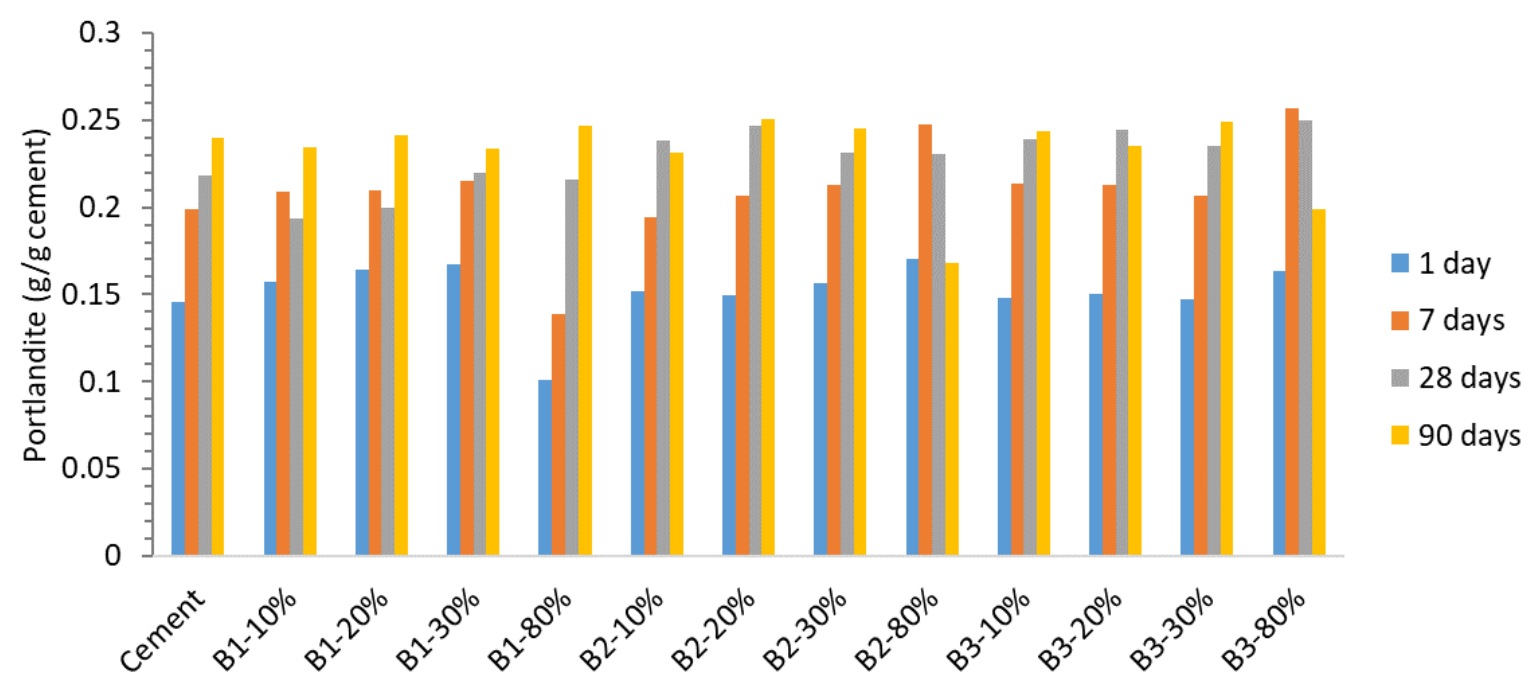

Figure 5 Quantity of portlandite ( $\mathrm{g} / \mathrm{g}$ cement) as a function of brick fines and substitution rate.

\subsubsection{Porosimetry analysis}

The evolution of the total porosity as well as the size distribution of the pores in the mixtures over time was studied using MIP. Firstly, analysis of the total porosity in Figure 6 revealed that for mixes with B1 and B2 fines, the total porosity of paste with $10 \%$ substitution rate was slightly higher or equal to that of the control pure cement paste. Total porosity increased afterwards with increasing substitution rate. A greater change in the porosity of microstructure was observed with coarser B3 fines, versus finer B1 and B2 fines. The pore size distributions for the samples are shown in Figure 7. At 90 days, a refinement of the distribution of pores was observed. A finer microstructure was noted with lower fines substitution rates. Mixtures with 
B3 were characterized by a more spread pore size distribution. After 90 days, the mixtures containing B2 fines presented the finest microstructure with more than $90 \%$ of the porosity consisting of pores with a diameter less than $1 \mu \mathrm{m}$ for all mixtures. However, mixes with B1 fines (despite their fineness) presented some coarser pores in microstructure probably due to agglomeration of brick fines. 

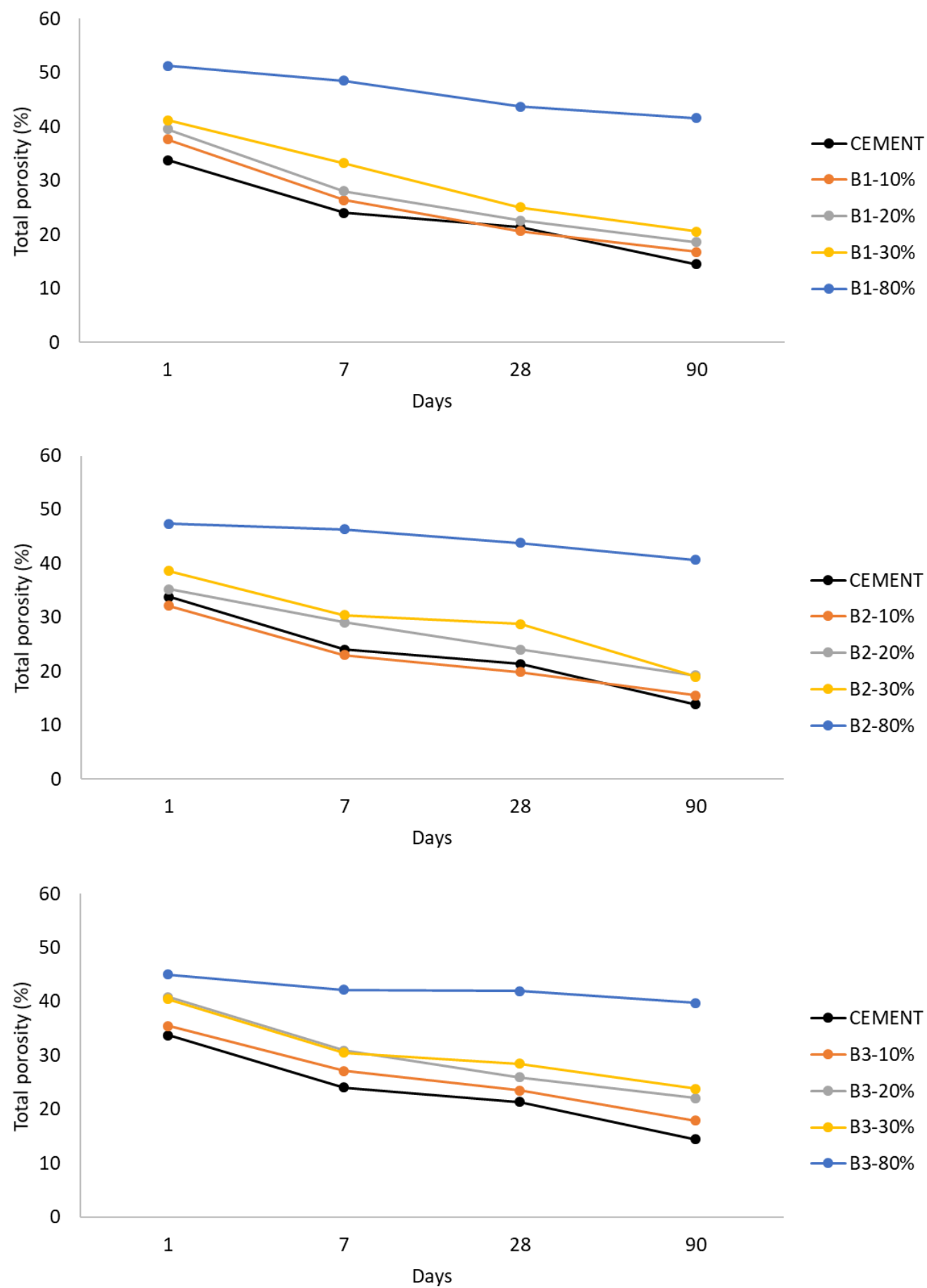

Figure 6-Evolution of total porosity over time. 


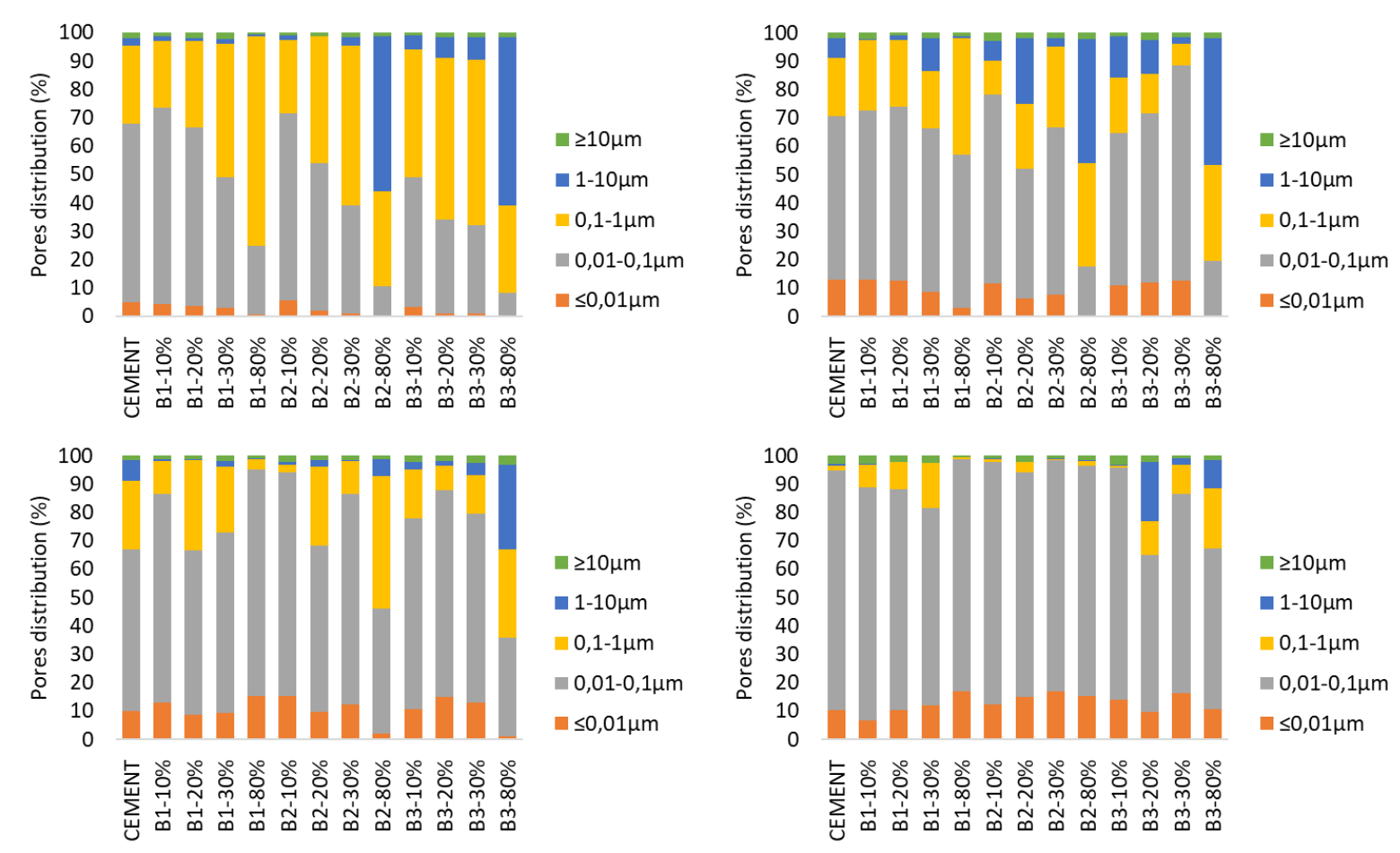

Figure 7-MIP analysis for B1, B2 and B3 mixes at 1, 7, 28 and 90 days.

\subsubsection{Compressive strength}

The compressive strength of pastes for the different substitution rates is presented in Figure 8 . A similar evolution for the three particle sizes was observed. The compressive strength of cement pastes decreased with the increasing proportion of brick fines for all the mixes with B1, B2 and B3 fines. Up to 28 days, samples with B1 fines had greater resistance than samples with B2 and B3 fines. At 90 days, the low substitution rates (10 and 20\%) with B2 seemed to be more efficient than B1 and B3 fines. The expected gain between 28 and 90 days with finer B1 fines was visible with higher substitution rates e.g. 30 and $80 \%$.

The strength activity index (SAI) was calculated with the ratio of compressive strenght of sample to the control cement and the results are shown in Figure 9. The SAI was studied to point out the impact of the pozzolanic activity of brick fines [17-39]. This index was calculated for each curing age and sample.

From 90 days, an index greater than 0.8 was noted for the lower substitution rate (10 and 20\%) of mixtures with B1 and B3, but not with B2 fines. On Figure 9, it can be obviously observed that the SAIs of B1 and B2 are slightly lower than 0.8 when the cement substitution rate is $20 \%$. 
The activity index at 90 days is increasing strongly for the mixture with $80 \%$ substitution rates (e.g. SAI $=0.4$ for mixture with $80 \% \mathrm{~B} 1$ ).

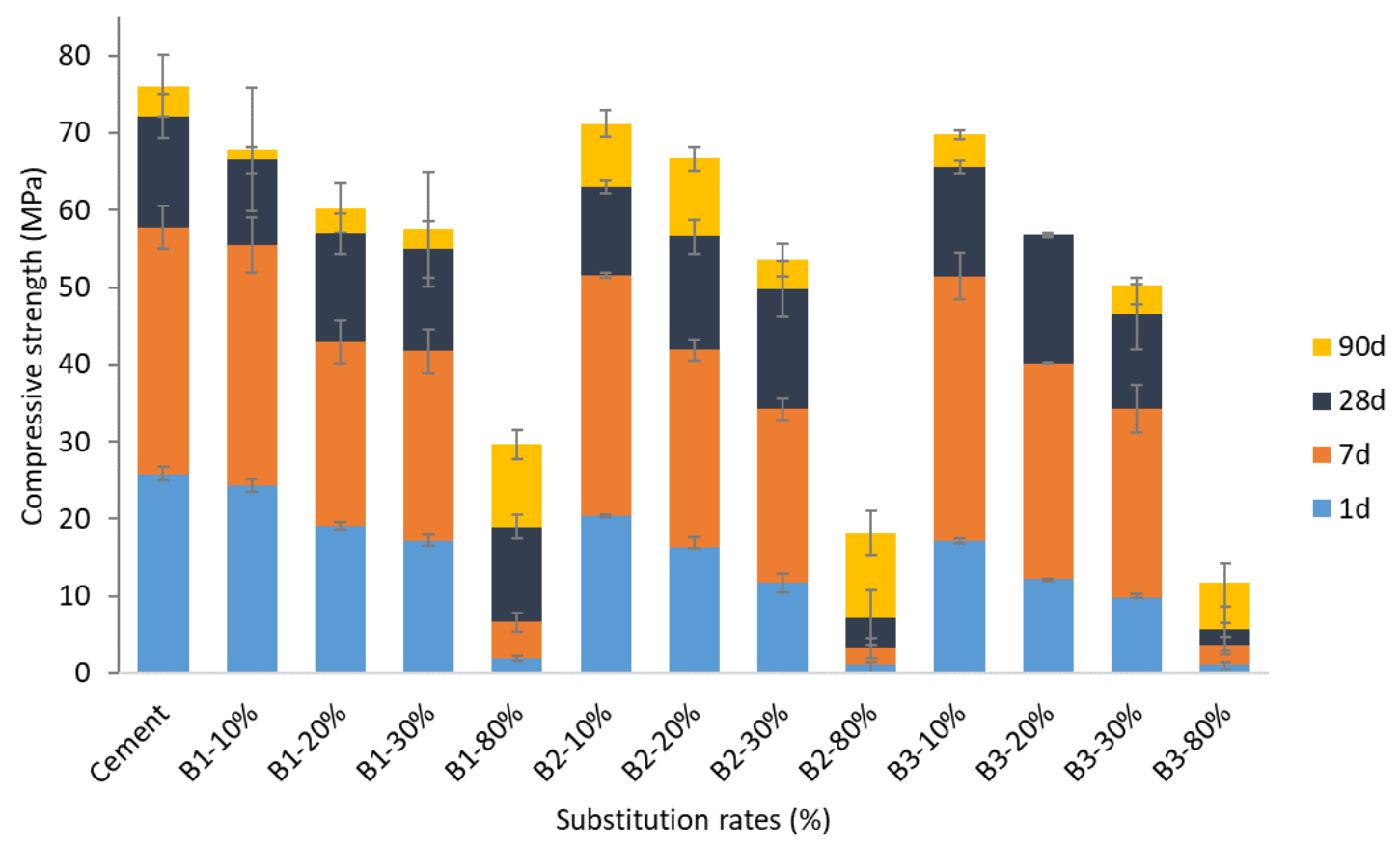

Figure 8 Compressive strength versus time.
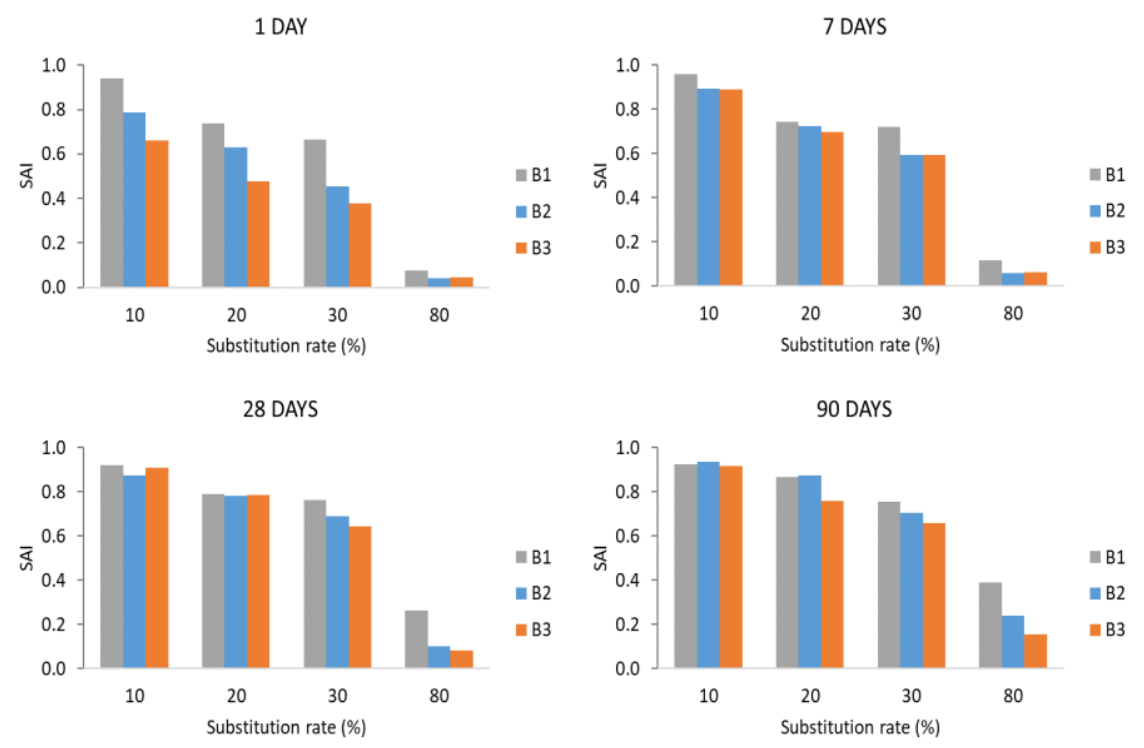

Figure 9-Strength Activity Index (SAI). 


\subsection{Discussion on hardened properties of cement pastes}

At a young age, the fine bricks favored hydradation through the nucleation effect. This effect was visible very early for B1 with an increase in the portlandite generated, seen in Figure 5, and good activity index value, seen in Figure 9. For B2 and B3, the portlandite generation took place a little later (Figure 5) and was accompanied by a catch-up in terms of activity index (Figure 9). In the longer term, the pozzolanic reaction occured with consumption of part of the portlandite generated by hydration. This was particularly observed for B2 and B3 at $80 \%$ with gains in mechanical strength (B1 at $80 \%$ presented an atypical value probably due to poor workability which would influence the results). At 90 days, the mechanical performances in Figures 8 and 9 , the substitution rates up to $20 \%$ showed results close to the control sample, in particular for B2. Beyond $20 \%$ substitution, the coarser the fines, the lower the mechanical performance was. The total porosity of all samples decreased with the development of hydration products (Figure 6) but the larger the size of the fines, the greater the porosity. A refinement of the porosity was also observed over time in relation to the advancement of hydration in Figure 7. The best result was obtained with B2. B3 being coarser, the pore distribution was more extensive. B1, despite its fineness, had a slightly wider distribution than B2, probably due to a possible agglomeration in view of fines. In the end, the best result at 90 days was obtained for the B2 fines up to $20 \%$ substitution.

A correlation between resistance and porosity results is noted: indeed, the total porosity of all samples decreased with the development of hydration products. However we also observed that the porosity was increasing with the size of the brick fines.

\subsection{Environmental considerations}

The analysis of the environmental impact in this study was carried out using the CML-IA baseline V3.0 [30,31]. The $\mathrm{CO}_{2}$ emissions released during the manufacture of cement and bricks are presented in Table 4. The initial manufacture of the bricks was less costly in terms of energy and $\mathrm{CO}_{2}$ emission, $227 \mathrm{~kg}$ of $\mathrm{CO}_{2} / \mathrm{t}$ and $800 \mathrm{~kg}$ of $\mathrm{CO}_{2} / \mathrm{t}$ for the brick and the cement respectively. 
With regard to the different manufacturing protocols for the three particle size distributions of brick fines, a difference in energy consumption was noted [19]. The energy used to produce the B1 brick fines $(0.15 \mathrm{MJ} / \mathrm{kg})$ is higher than that for cement powder $(0.13 \mathrm{MJ} / \mathrm{kg})$. The consumption of energy for the production of B2 and B3 fines was lower than that for cement. In view of all the results obtained (comparison between performances and energetic cost), the B2 fines would present the best compromise in accordance with the results. Of course, other parameters should be taken into account (transport, resources,...) for an accurate evaluation of environmental impact and life cycle analysis [40,41].

Table 4-Carbon emission and energy intensity.

\begin{tabular}{ccc} 
& Cement & Brick fines \\
\hline $\mathrm{CO}_{2}$ emission $(\mathrm{kg} / \mathrm{t})$ & 800 & 227 \\
& & $\mathrm{~B} 1: 0.15$ \\
Energy grinding & 0.13 & $\mathrm{~B} 2: 0.08$ \\
intensity $(\mathrm{MJ} / \mathrm{kg})$ & & B3: 0.02 \\
\hline
\end{tabular}

\section{Conclusions}

The feasibility of using different particle sizes of brick fines as supplementary cementitious materials has been researched, and the following conclusions can be drawn from the study:

- The pozzolanic activity of brick fines was related to the particle size and specific surface area. The grinding of the fines led to an increase in this pozzolanic activity. However, too much grinding could lead to agglomeration of the brick fines and thus less efficiency, which also consumes more energy.

- In the fresh state, in the case of the finest brick particles, their higher specific surface area is higher and it leads to reduced workability. The water requirement for fines below $10 \mu \mathrm{m}$ (B1) was higher than for control material with 100\% cement powder. For mixes with fines B2 and B3, workability was improved, which is probably due to the higher packing density of the mix. The setting time increased with the substitution rate of fines. 
However, this setting time was reasonably increasing up to $20 \%$ substitution rate, except for the final setting time of the mixtures B1-10\% and B1-20\% which decreased.

- In the hardened state, a nucleation effect was observed from 1 day for B1 and later for B2 and B3. Then the pozzolanic reaction took over for older ages. The results obtained with three different brick fines showed a non-proportional effect between fineness, strength gain and microstructure refinement. The mixes with B2 fine, whose $\mathrm{d}_{50}$ is very close to cement, presented at 90 days the best refinement of microstructure but also the best compressive strength results (up to $20 \%$ substitution rate).

- From an environmental point of view, the manufacture of bricks emitted less $\mathrm{CO}_{2}$ than Portland cement. The production of brick fines of a particle size close to a cement powder was less energy intensive.

- The reuse of brick fines was optimal for brick fines with a grain size close to the associated binder and with substitution rates up to $20 \%$. Beyond $20 \%$ substitution rate, the environmental gain increased but this did not compensate for the decrease in technical performances of the material.

A follow-up to this study will be the evaluation of performance of mortar and concrete produced with this brick fines blended cement. Durability performances also have to be evaluated. Additionally, the rheological study of type B1 fines could help to understand their behaviour in the mixture. Indeed, based on the results of the paste flow, an improvement in mechanical resistance could be seen by playing with W/B as well as the addition of superplasticizer. Working at constant workability would probably allow a better refinement of the microstructure as well as higher mechanical strength for high substitution rates with B2 and B3 brick fines.

\section{Acknowledgments}

The authors thank INISMA and the CTP for their participation in the preparation and characterization of brick fines materials. Dr. Sylvie Groslambert is also thanked for the data collection and the calculation for the energy production part. This research was supported through the Interreg VALDEM project "Integrated solutions for the recovery of material flows resulting from the demolition of buildings: a cross-border approach towards a circular 
economy" (Interreg France-Wallonie-Vlaanderen Convention No. 1.1.57, 2014-2020). he authors would like to thank Ms. Charlotte Colman for her careful proofreading.

\section{REFERENCES}

[1] Nili, M, and Salehi, A. M. Assessing the effectiveness of pozzolans in massive high-strength concrete, Construction and Building Materials 24: 2108-16 (2010) doi:10.1016/j.conbuildmat.2010.04.049.

[2] Abib, Z.E, Gaher-Abib, H, Kharchi, F, Effect of clay fines on the behavior of selfcompacting concrete, Engineering, 05 213-218 (2013) doi:10.4236/eng.2013.52031.

[3] Directive 2008/98/CE Du Parlement Européen et du Conseil du 19 novembre 2008, relative aux déchets et abrogeant certaines directives.

[4] Pacheco-Torgal, F, and Jalali, S, Reusing ceramic wastes in concrete, Construction and Building Materials 24: 832-38 (2010) doi:10.1016/j.conbuildmat.2009.10.023.

[5] Courard, L, Darimont, A, Schouterden, M, Ferauche, F, Willem, X, Degeimbre, R, Durability of mortars modified with metakaolin, Cem. Concr. Res. 33 1473-1479 (2003) doi:10.1016/S0008-8846(03)00090-5.

[6] Tuyan, M, Andiç-Çakir, Ö, and Ramyar, K, Effect of alkali activator concentration and curing condition on strength and microstructure of waste clay brick powder-based geopolymer, Composites Part B: Engineering 135: 242-52 (2018) doi:10.1016/j.compositesb.2017.10.013.

[7] El-Gamal, S. M. A, El-Hosiny, F. I, Amin, M. S, and Sayed, D. G, Ceramic waste as an efficient material for enhancing the fire resistance and mechanical properties of hardened Portland cement pastes, Construction and Building Materials 154: 1062-78 (2017) doi:10.1016/j.conbuildmat.2017.08.040.

[8] Arvaniti, E.C, Juenger, M, Bernal, S.A, Duchesne, J, Courard, L, Leroy, S, Provis, J, Klemm, A, De Belie. N, Physical characterization methods for supplementary cementitious materials, Mater Struct 48(11): 3675-3686 (2015) doi:10.1617/s11527-014-0430-4.

[9] Aliabdo, Ali A, Abd-Elmoaty, M, and Hani H.Hassan, Utilization of crushed clay brick in concrete industry, Alexandria Engineering Journal 53: 151-68 (2014) doi:10.1016/j.aej.2013.12.003.

[10] Katzer, J, Strength performance comparison of mortars made with waste fine aggregate and ceramic fume, Construction and Building Materials 47: 1-6 (2013) doi:10.1016/j.conbuildmat.2013.04.039. 
[11] Letelier, V, Tarela, E, and Moriconi, G, Mechanical properties of concretes with recycled aggregates and waste brick powder as cement replacement, Procedia Engineering 171: 627-32 (2017) doi:10.1016/j.conbuildmat.2013.04.039.

[12] Ortega, J.M, Letelier, V, Solas, C, Moriconi, G, Climent, M.A, and Sánchez, I, Long-term effects of waste brick powder addition in the microstructure and service properties of mortars, Construction and Building Materials 182: 691-702 (2018) doi:10.1016/j.conbuildmat.2018.06.161.

[13] Puertas, F, García-Díaz, I, Barba, A, Gazulla, M.F, Palacios, M, Gómez, M. P, MartínezRamírez, S, Ceramic wastes as alternative raw materials for Portland cement clinker production, $\begin{array}{llllll}\text { Cement and Concrete } & \text { Composites } 30 & \text { (9): } \quad 798-805 & \text { (2008) }\end{array}$ doi:10.1016/j.cemconcomp.2008.06.003.

[14] Liu, Q, Tong, T, Liu, S, Yang, D, Yu, Q, Investigation of using hybrid recycled powder from demolished concrete solids and clay bricks as a pozzolanic supplement for cement, $\begin{array}{llllll}\text { Construction and } & \text { Building } & \text { Materials } & \text { 734 } & \text { (2014) }\end{array}$ doi:10.1016/j.conbuildmat.2014.09.066.

[15] Pereira-de-Oliveira, Luiz A, Castro-Gomes, João P, Pedro M.S. Santos, The potential pozzolanic activity of glass and red-clay ceramic waste as cement mortars components, $\begin{array}{llllll}\text { Construction and } & \text { Building } & \text { 31: } & \text { (2012) }\end{array}$ doi:10.1016/j.conbuildmat.2011.12.110.

[16] Li, L. G, Lin, Z. H, Chen, G. M, Kwan, A. K. H, Reutilizing clay brick dust as paste substitution to produce environment-friendly durable mortar, Journal of Cleaner Production 274: 122787 (2020) doi:10.1016/j.jclepro.2020.122787.

[17] Yang, D., Lui, M., and Ma, Z., 2020. "Properties of the Foam Concrete Containing Waste Brick Powder Derived from Construction and Demolition Waste." Journal of Building Engineering 32 : 101509. https://doi.org/10.1016/j.jobe.2020.101509.

[18] Ge, Z, Wang, Y, Sun, R, Wu, X, Guan, Y, Influence of ground waste clay brick on properties of fresh and hardened concrete, Construction and Building Materials 98: 128-36 (2015) doi:10.1016/j.conbuildmat.2015.08.100.

[19] Zhao, Y, Gao, J, Liu, C, Chen, X, Xu, Z, The particle-size effect of waste clay brick powder on its pozzolanic activity and properties of blended cement, Journal of Cleaner Production 242: 118521 (2020) doi:10.1016/j.jclepro.2019.118521.

[20] Li, H, Dong, L, Jiang, Z, Yang, X, Yang Z, Study on utilization of red brick waste powder in the production of cement-based red decorative plaster for walls, Journal of Cleaner Production 133: 1017-26 (2016) doi:10.1016/j.jclepro.2016.05.149.

[21] Viani, A, Sotiriadis, K, Len, A, Šašek, P, Ševčík, R, Assessment of firing conditions in old fired-clay bricks: the contribution of X-ray powder diffraction with the Rietveld method and 
small angle neutron scattering, Materials Characterization 116: 33-43 (2016) doi:10.1016/j.matchar.2016.04.003.

[22] Bouarroudj, M. E, Remond, S, Grellier, A, Bulteel, D, Michel, F, Zhao, Z, Courard, L, Determination of the porosity of powder: modeling and experimentation. submitted to Material and structure (2020).

[23] AFNOR NF EN 1097-7 Essais pour déterminer les caractéristiques mécaniques et physiques des granulats-Partie 7: Détermination de la masse volumique absolue - Méthode au pycnomètre.

[24] AFNOR NF EN 196-5 Méthodes d'essais des ciments-Partie 5: Essai de pouzzolanicité des ciments pouzzolaniques.

[25] ASTM C618 Standard Specification for coal fly ash a nd raw or calcined natural pozzolan for use in concrete.

[26] Navrátilová, E, Rovnaníková, P, Pozzolanic properties of brick powders and their effect on the properties of modified lime mortars, Construction and Building Materials 120: 530-39 (2016) doi:10.1016/j.conbuildmat.2016.05.062.

[27] AFNOR NF EN 196-1 Méthodes d'essais des ciments-Partie 1: Détermination des résistances (2016).

[28] AFNOR NF EN 1015-3 Méthode d'essai des mortiers pour maçonnerie-Partie 3 : Détermination de la consistance du motier frais (à la table à secouss).

[29] AFNOR NF EN 196-3 Méthodes d'essais des ciments-Partie 3: Détermination du temps de prise et de la stabilité.

[30] Guinée J.B, Gorrée M, Heijungs R, Huppes G, Kleijn R, Koning A de, Oers L.F.C.M. van, Wegener Sleeswijk A, Suh S, Udo de Haes H.A, Bruijn H. de, Duin R. van Huijbregts M.A.J, Handbook on life cycle assessment: operational guide to the ISO standards, Dordrecht: Kluwer Academic Publishers, (2002) The Netherlands.

[31] Wernet, G, Bauer, C, Steubing, B, Reinhard, J, Moreno-Ruiz, E, Weidema, B, The ecoinvent database version 3 (part I): overview and methodology, The International Journal of Life Cycle Assessment, 21(9), pp.1218-1230 (2016).

[32] Le Saoût, G, Kocaba, V, Scrivener, K, Application of the Rietveld method to the analysis of anhydrous cement, Cement and Concrete Research 41 (2): 133-48 (2011) doi:10.1016/j.cemconres.2010.10.003.

[33] Wong, C.L, Hung Mo, K, Poh Yap, S, Johnson Alengaram, U, Ling, T.C, Potential use of brick waste as alternate concrete-making materials: a review, Journal of Cleaner Production 195: 226-39 (2018) doi:10.1016/j.jclepro.2018.05.193. 
[34] Wild, S, Gailius, A, Hansen, H, Pederson, L, Szwabowski, J, Pozzolanic properties of a variety of European clay bricks, Building Research \& Information 25 (3): 170-75 (1997) doi:10.1080/096132197370435.

[35] Andriolo, F.R, Sgaraboza B.C, Proceedings of the 7th International Conference of AAR,Ed. Grattan-Bellow, pp. 66-70.1985.

[36] Sabir, B. B, Wild, S, Bai, J, Metakaolin and calcined clays as pozzolans for concrete: A Review, Cement and Concrete Composites, Metakaolin and Calcined Clays, 23 (6): 441-54 (2001) doi:10.1016/S0958-9465(00)00092-5.

[37] Zhao, Z, Remond, S, Damidot, D, Xu, X, Influence of fine recycled concrete aggregates on the properties of mortars, Construction and Building Materials 81:179-186 (2015). doi:10.1016/j.conbuildmat.2015.02.037.

[38] Brooks, J.J, Megat Johari, M.A, Mazloom, M, Effect of admixtures on the setting times of high-strength concrete, Cement and Concrete Composites 22: 293-301 (2000) doi:10.1016/S0958-9465(00)00025-1.

[39] Maia de Souza, D, Lafontaine, M, Charron-Doucet, F, Chappert, B, Kicak, K, Duarte, F, Lima, L, Comparative life cycle assessment of ceramic brick, concrete brick and cast-in-place reinforced concrete exterior walls, Journal of Cleaner Production 137: 70-82 (2016) doi:10.1016/j.jclepro.2016.07.069.

[40] Mouhamadou, A, Benzerzour, M, Abriak, N-E, Mamindy-Pajany. Y, Study of the pozzolanic activity of a dredged sediment from dunkirk harbour, Powder Technology 320: 74864 (2017) doi:10.1016/j.powtec.2017.07.055.

[41] Zhao, Z, Courard, L, Groslambert, S, Jehin, T, Léonard, A, Xiao, J, Use of recycled concrete aggregates from precast block for the production of new building blocks: An industrial scale study, Resources, Conservation \& Recycling 157: 104786 (2020) doi:10.1016/j.resconrec.2020.104786. 